\title{
Debate
}

\section{Is Patient Choice the Future of Health Care Systems?}

\author{
Marianna Fotaki* \\ Warwick Business School, University of Warwick, Coventry, UK
}

Received: 17 July 2013, Accepted: 11 August 2013, ePublished: 12 August 2013

\begin{abstract}
Patient and user choice are at the forefront of the debate on the future direction of health and public services provision in many industrialized countries in Europe and elsewhere. It is used both, as a means to achieve desired policy goals in public health care systems such as greater efficiency and improved quality of care, and as a good with its own intrinsic value. However, the evidence suggests that its impact on efficiency and quality is at best a very limited while it might have negative consequences on equity because the pre-existing inequalities of income and education could influence patients' access to information and, consequently, choices. The paper attempts to introduce multidisciplinary frameworks to account for the social and cultural factors guiding patients' choices and to explain the rationale, processes and outcomes of decision making in health care.
\end{abstract}

Keywords

Patient Choice, Efficiency, Quality of Care, Market, Public Good, Health Ethics

\section{Introduction}

Patient and user choice are at the forefront of the debate on the future direction of health and public services provision in many industrialized countries in Europe and elsewhere (1). Choice over who, when and what services will be provided to patients by competing hospitals is a prominent aim of health reforms in many other countries (2). Individual patient choice is now seen both as a means to achieve desired policy goals in public health care systems such as greater efficiency and improved quality of care, and as a good with its own intrinsic value (3).

This is particularly, true for tax-financed health care systems such that of the UK (4), Scandinavia (5) or New Zealand (6) where there was historically little individual choice. In such instances, primary care physicians acted as gatekeepers in the system, making the bulk of health care related decisions on behalf of their patients. However, choice can be used to achieve various policy goals. For instance, in social health insurance systems where patients have greater opportunity to select where to receive their treatments, choice reforms are less pronounced. For instance, in Germany and the Netherlands, market reforms were introduced to induce price competition between hospitals and/or insurers $(7,8)$ who could be freely chosen by patients. The rapidly rising cost of health care has forced policy makers to curtail individual patient choice in the marketised health care system of the USA (9) too. Under the managed care reforms, choice of provider and available forms of treatment is usually restricted by the insurer and is largely determined by the users' ability to pay.

\section{Why choice and why now?}

Although the causes of reliance on the market means in health policy making are multiple, consumerist choice is also an ideological proposition that is firmly rooted in neo-classic economics. It is central to market liberalism, given its focus on property rights, individual freedom, competition and the emphasis on self-interest as the driver of human behaviour. After the demise of alternative economic models in the 1990s this has become a dominant doctrine for public policy governance in the Western world and beyond. The rationale driving these changes is simple: The provision of relevant and usable information for patients enabling them to exercise their right of exit will, it is presumed, create empowered consumers of health services prompting health providers to both disclose information on their performance and improve it or close down.

In addition to choice being used as an instrument for achieving desirable policy goals of efficiency, better quality, responsiveness to users' needs or even equity (10), the emphasis now is on the value it represents for them. The idea of patients as choosers shaping service provision is enmeshed with the long standing users' demands for autonomy and greater control over health care resources (11). Various theories of post-modernity have been often unproblematically called upon to argue that their desire for more information and more equal relation with health care professionals implies a demand for consumerist choice (12). Introducing choice in publicly funded and provided health care systems is thus seen as a response to the demands of the middle class (13). Yet think-tanks and various academic networks often supported by corporations have played an essential role in promoting this discourse in order to enable the outsourcing of public institutions to the private market in the USA (14) and the UK (15). 
Does patient choice improve efficiency and quality of health care?

However, the market in health care has until now not worked in ways that economic models predicted and policy makers expected. The research suggests that the impact of a 'choice' policy in health care is unpredictable. Choice examined in the context of pro-market reforms in the UK and in other comparable health systems in the 1990s indicates at best a very limited impact of such policies in terms of efficiency and quality (16), while there were indications of its negative impact on equity since some patients received preferential access and treatment (17). A review of users' uptake of choice in England and elsewhere found only moderate interest in the choices offered (18). The availability of good quality health services provided locally and retaining the public and universal aspects of the health system is much higher on patients' agendas (19). Further, patients appear to be more interested in choosing treatments rather than providers which is determined by a variety of factors in complex relation to each other and not by a simple notion of preference, indicating the context specific nature of choices in health. These included the patient's beliefs, cultural values, and expectations, personal characteristics such as gender, age, education and the severity of medical condition (20). The application of rational choice theory to understanding agency in health care is flawed because it ignores the effect of the vulnerability that comes with ill health and does not consider in any depth the imperfections of the human mind in processing information (21). Nor does it account for how the pre-existing inequalities of income and education could impact on patients' access to information and therefore choices.

Thus; the use of market-type choice to promote competition in health insurance and health care delivery, to increase efficiency, and improve quality through more incentives for better coordination of care, poses serious limitations. Although it is possible to treat people who seek professional help as customers, this undermines ways of thinking and acting crucial to health care: good care is not a matter of making well-argued individual choices but is something that grows out of collaborative and continuing attempts to attune knowledge and technologies to diseased bodies and complex lives (22).

\section{Is patient choice a future of health systems?}

A direct replication of theoretical frames and methodologies from economics and business literature is not sufficient or adequate for understanding how users make choices in public services. Nor are theoretical ideal-type constructs of the rational actor and socially dis-embedded individual currently dominating policy debates of use as a sound base for policy making. This economic tunnel vision in policy making needs to be broken since this is only one and not the most suited way governing health care service provision. Theories from outside economics offering sociologically, culturally and ethically embedded notion of agency and human action need to be drawn on to explain the rationale, processes and outcomes of decision making in health care.

The business language used to describe health care as a market transaction misses the fact that health care is unlike other commodities: having had choice, few would have opted to consume health care for the sake of it. Placing such an expectation on the users of services in time of ill health implicitly connects their choices with responsibilities. This might not only lead to socially undesirable outcomes with individual preferences superseding the notion of the public good and the logic of care but also raises serious moral dilemmas that may be against our societal values.

\section{Ethical issues}

Not applicable.

Competing interests

The author declares that he has no competing interests.

Author's contribution

MF is the single author of the manuscript.

\section{References}

1. Williams J, Rossiter A. Choice: the evidence. The operation of choice systems in practice: national and international evidence. London: The Social Market Foundation; 2004.

2. Beusekom I, Tönshoff S, de Vries H, Spreng C, Keeler EB. Possibility or utopia? Consumer choice in health care: A literature review. Santa Monica: RAND Corporation; 2004.

3. Le Grand J. The other invisible hand. Princeton University Press; 2007.

4. Department of Health. Fair for all, personal to you. A consultation on choice, responsiveness and equity. London: Department of Health; 2003.

5. Vrangbæk K, Østergren K, OkkelsBirk H, Winblad U. Patient reactions to hospital choice in Norway, Denmark and Sweden. Health Econ Policy Law 2007; 2: 125-52.

6. Ashton T, Mays N, Devlin N. Continuity through change: the rhetoric and reality of health reform in New Zealand. Soc Sci Med 2005; 61: 253-62.

7. Vaillancourt-Rosenau $P$, Lako C. An experiment with regulated competition and individual mandates for universal health care: The new Dutch health insurance system. J Health Polit Policy Law 2008; 33: 1031-52.

8. Lisac M. Health care reform in Germany: Not the big bang. Health Policy Monitor. 2006. [cited 2013 July 13]. Available from: http://www. hpm.org/en/Surveys/Bertelsmann_Stiftung_-_Germany/08/Health_ care_reform_in_Germany_Not_the_big_bang.html

9. Gray B. Trust and trustworthy care in the managed care era. Health Aff 1997; 16: 34-49.

10. Blair A. We must not waste this precious period of power. Speech given at South Camden Community College, 23 January 2003.

11. Fotaki M. Towards developing new partnerships in public services: users as consumers, citizens and/or co-producers driving improvements in health and social care in the UK and Sweden. Public Adm 2011; 89: 933-95.

12. Giddens A. Living in a post-traditional society. In: Beck U, Giddens A, Lash S, eds. Reflexive modernisation: politics, traditions and aesthetics in the modern social order. Cambridge: Polity; 1994.

13. Blomqvist $P$. The choice revolution: privatization of Swedish welfare services in the 1990s. Soc Policy Adm 2004; 38: 139-55.

14. Barley S. Building an institutional field to corral a government: A case to set an agenda for organization studies. Organization Studies 2010; 31: 777-805.

15. Paton C. Garbage-can policy and neo-liberal ideology: 25 years of redundant re-form in the English NHS. Soc Policy Adm 2013, forthcoming.

16. Le Grand J, Mays N, Mulligan JA. Learning from the NHS internal market. A review of the evidence. London: King's Fund; 1998.

17. Mannion R. Practice-based budgeting: lessons from the past; prospects for the future. Report to the Department of Health. York: Centre for Health Economics, University of York; 2005. 
18. Fotaki M, Roland M, Boyd A, McDonald R, Scheaff R, Smith L. What benefits will choice bring to patients? Literature review and assessment of implications. J Health Serv Res Policy 2008; 13: 178-84.

19. 2020 Public Services Trust 2010. What people want, need and expect from public services. London: 2020 Public Services Trust at RSA prepared by Ipsos MORI.

20. Fotaki M, Boyd A, Smith L, Ruth McDonald R, Roland M, Sheaff R, et al. Patient choice and the organisation and delivery of health services: Scoping review. A report to the NCCSDO. London, 2006.

21. Kahneman D, Tversky A. Prospect theory: An analysis of decision under risk. Econometrica 1979; 47: 263-91.

22. Mol A. The logic of care. London: Routledge; 2008. 